\title{
Chondrosarcoma presenting as a rare primary malignant tumour of the chest wall
}

\author{
Calvin Abro, ${ }^{\oplus 1}$ Khader Herzallah, ${ }^{2}$ Fawzi Abu Rous, ${ }^{1}$ Yehia Saleh ${ }^{\oplus 1}$
}

'Internal Medicine, Michigan State University, East Lansing, Michigan, USA

${ }^{2}$ Internal Medicine, Michigan State University/Sparrow Hospital, East Lansing, Michigan, USA

Correspondence to Dr Calvin Abro, abrocalv@msu.edu

Accepted 1 May 2019

\section{DESCRIPTION}

A 74-year-old man with a previous medical history of hypertension, type 2 diabetes mellitus and gastro-oesophageal reflux presented with acute hypoxic respiratory failure. The patient was aware of a mass on his sternum for $\sim 18$ years prior to presentation and was told by his previous healthcare provider that it was a benign enchondroma. He remained asymptomatic for most of the duration of the mass until a few months prior to seeing another medical provider after experiencing increasing pain and size of the mass. A computed tomography (CT)-guided core biopsy was done and revealed a well-differentiated chondrosarcoma (figure 1). Shortly after biopsy, the patient noticed increased weight loss and rapid growth of the mass. Concerned for rapid tumour progression, a repeat positron emission tomography (PET)-CT scan showed extensive retrosternal, lung, phrenic nerve and pericardial involvement causing mass effect on the heart that was deemed inoperable by a thoracic oncology surgeon (figure 2). He underwent two rounds of treatment with pembrolizumab. Biopsies were done of the sternum and lung nodule at this time because of concern of dedifferentiation. These biopsies again showed well-differentiated chondrosarcoma. Having made no progress with pembrolizumab, he was started on liposomal doxorubicin. A month after receiving his first round of liposomal doxorubicin, he presented to the emergency department with increased difficulty in breathing requiring $4 \mathrm{~L}$ of oxygen and lower extremity oedema. An echocardiogram was obtained which showed a left ventricular ejection fraction of $65 \%$. A CT angiogram was also done to rule out an acute pulmonary embolism (PE) and

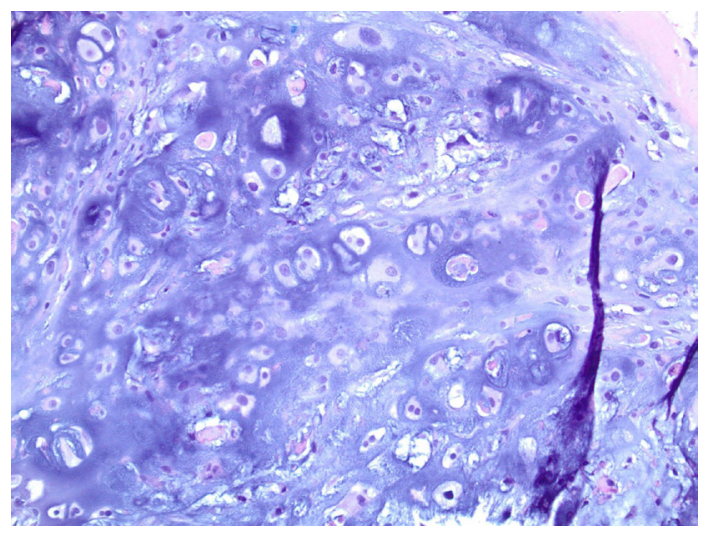

Figure 1 Histology of the chondrosarcoma biopsied from chest wall.

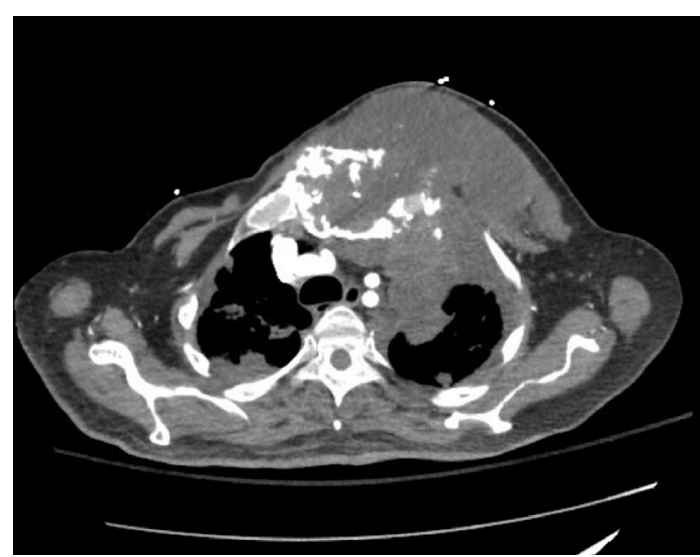

Figure 2 CT of the chest showing chondrosarcoma of the chest wall with extensive mediastinal involvement.

although no PE was found, there was compressive atelectasis of the left lung. Pulmonology was consulted and recommended against endobronchial stent placement in light of significant tumour burden. A few days after being admitted the patient's oxygen requirement increased requiring $60 \%$ oxygen via high flow nasal cannula. Despite these efforts, the patient ultimately went into cardiopulmonary arrest and died.

Primary malignant tumours of the chest wall make up approximately $<1 \%$ of all primary tumours. ${ }^{1}$ They are among the rarest cartilage tumours with chondrosarcomas encompassing $15 \%$ of the cases. ${ }^{2}$ Our patient was initially diagnosed with an enchondroma presumably due to the rarity of chondrosarcomas of the chest. No records of any biopsies were available as the diagnosing physician resided in another country. Both can present with a slow-growing mass that can be non-tender and later become painful due to lytic bony destruction. ${ }^{3}$ Our patient's mass resulted in a malignant tumour that may have otherwise been treated with surgical resection. Nevertheless, even if the lesion were an enchondroma, these tumours can malignantly degenerate into chondrosarcomas-necessitating close follow-up. ${ }^{3}$ In one study, the single most important factor that predicted a favourable outcome was the ability to perform a complete resection of the tumour with survival reaching $80 \%$ at 5 years. ${ }^{4}$ Unfortunately, our patient had widespread disease which was not amenable to complete surgical resection. Instead, he received the programmed death-ligand 1 (PDL-1) inhibitor-pembrolizumab-which one phase II trial 
recently reported a partial response rate of only $25 \%$ in five patients with chondrosarcoma. ${ }^{5}$

\section{Learning points}

- Although enchondromas are regarded as benign growths, they may malignantly degenerate into chondrosarcomas.

- The most important factor that predicts a favourable survival is wide resection of the primary malignant tumour of the chest wall.

Contributors $\mathrm{CA}$ and $\mathrm{KH}$ created the initial manuscript. FAR and YS revised the manuscript.

Funding The authors have not declared a specific grant for this research from any funding agency in the public, commercial or not-for-profit sectors.
Competing interests None declared.

Patient consent for publication Next of kin consent obtained.

Provenance and peer review Not commissioned; externally peer reviewed.

\section{REFERENCES}

1 Athanassiadi K, Kalavrouziotis G, Rondogianni D, et al. Primary chest wall tumors: early and long-term results of surgical treatment. Eur J Cardiothorac Surg 2001;19:589-93.

2 Waisberg DR, Abrão FC, Fernandez A, et al. Surgically-challenging chondrosarcomas of the chest wall: five-year follow-up at a single institution. Clinics 2011;66:501-3.

3 Somers J, Faber LP. Chondroma and chondrosarcoma. Semin Thorac Cardiovasc Surg $1999 ; 11: 270-7$

4 Martini N, Huvos AG, Burt ME, et al. Predictors of survival in malignant tumors of the sternum. J Thorac Cardiovasc Surg 1996;111:96-106.

5 Chow WA. Faculty of 1000 evaluation for Pembrolizumab in advanced soft-tissue sarcoma and bone sarcoma (SARC028): a multicentre, two-cohort, single-arm, openlabel, phase 2 trial: F1000 - Post-publication peer review of the biomedical literature, 2018.

Copyright 2019 BMJ Publishing Group. All rights reserved. For permission to reuse any of this content visit

https://www.bmj.com/company/products-services/rights-and-licensing/permissions/

BMJ Case Report Fellows may re-use this article for personal use and teaching without any further permission.

Become a Fellow of BMJ Case Reports today and you can:

- Submit as many cases as you like

- Enjoy fast sympathetic peer review and rapid publication of accepted articles

- Access all the published articles

- Re-use any of the published material for personal use and teaching without further permission

\section{Customer Service}

If you have any further queries about your subscription, please contact our customer services team on +44 (0) 2071111105 or via email at support@bmj.com.

Visit casereports.bmj.com for more articles like this and to become a Fellow 